\title{
Insights into the evolutionary and demographic history of the extant endemic rodents of the Galápagos Islands
}

\author{
Susette Castañeda-Rico ${ }^{1,2,3 *}$, Sarah A. Johnson ${ }^{2,5}$, Scott A. Clement ${ }^{4}$, Robert C. Dowler ${ }^{4}$, Jesús E. Maldonado ${ }^{1,2}$, and Cody W. Edwards 2,3 \\ ${ }^{1}$ Center for Conservation Genomics, Smithsonian Conservation Biology Institute, National Zoological Park, Washington, DC \\ 20008, U.S.A. Email: susetteazul@gmail.com castanedaricos@si.edu (SCR), maldonadoj@si.edu (JEM). \\ ${ }^{2}$ George Mason University, Fairfax, VA 22030, U.S.A. Email: Sarah.Johnson@tceq.texas.gov (SAJ), cedward7@gmu.edu (CWE). \\ ${ }^{3}$ Smithsonian-Mason School of Conservation, Front Royal, VA 22630, U.S.A. \\ ${ }^{4}$ Angelo State University, Department of Biology, San Angelo, TX 76909, U.S.A. Email: scott.clement@templejc.edu (SAC), robert. \\ dowler@angelo.edu (RCD). \\ ${ }^{5}$ Commission on Environmental Quality (TCEQ) 12100 Park 35 Circle, Mail Code 148, Austin, TX 78753, USA. \\ ${ }^{*}$ Corresponding author
}

Evolutionary radiations stemming from colonization of archipelagos provide valuable insights into mechanisms and modes of speciation. For this reason, the fauna inhabiting the Galápagos Islands has been the focus of numerous emblematic ecological and evolutionary studies. However, studies focused on rodents have been scarce. Rice rats radiated in situ into at least six endemic species: Aegialomys galapagoensis, Nesoryzomys narboroughi, N. swarthi, N. fernandinae, N. indefessus, and N. darwini. Only the first four species remain extant on the archipelago. These species are considered vulnerable, mainly due to human activities and invasive species. Despite their interesting evolutionary history, questions surrounding phylogenetic relationships, colonization events, genetic diversity and demography of populations remain unresolved. We used the D-loop region of mtDNA to infer phylogenetic relationships, colonization events, date divergences, and conduct population genetic analyses of the four extant endemic species inhabiting the Galápagos Islands. We found that all species were monophyletic. A. galapagoensis is sister to A. xanthaeolus from the continent, and both of them are the sister clade of the genus Nesoryzomys. Our results also showed that there were two colonization events to the islands. The first event was the arrival of the ancestor of Nesoryzomys during the Pliocene, when divergences between genera occurred. The second was Aegialomys during middle Pleistocene, when species diversification began. Populations on each island show high genetic diversity and most show signals of recent expansion. However, future studies are needed to accurately assess the conservation status of these populations. We suggest ongoing monitoring of these vulnerable endemic species, including ecological and population genetic studies. In addition, future studies using genome-wide molecular markers and additional species from the continent, as well as sampling extinct species from the islands, will improve our knowledge about the origin and relationships of the endemic rodents of the Galápagos Islands.

Las radiaciones evolutivas que ocurren en los archipiélagos, posterior a su colonización, proporcionan información relevante sobre las formas y mecanismos de especiación. Por tal motivo, la fauna que habita en las Islas Galápagos ha sido objeto de numerosos y emblemáticos estudios. A pesar de lo anterior, los estudios enfocados a roedores han sido escasos. Las ratas arroceras han radiado in situ en al menos seis especies endémicas: Aegialomys galapagoensis, Nesoryzomys narboroughi, N. swarthi, N. fernandinae, N. indefessus y N. darwini. A la fecha, solo las primeras cuatro especies aún se distribuyen en el archipiélago. Dichas especies se encuentran clasificadas como vulnerables, debido principalmente a las actividades humanas y las especies invasoras. A pesar de la interesante historia evolutiva que presentan estas especies, las interrogantes sobre sus relaciones filogenéticas, los eventos de colonización de las islas y la diversidad genética e historia demográfica de sus poblaciones, siguen sin resolverse. Dado lo anterior, usamos la región D-loop del DNA mitocondrial para inferir las relaciones filogenéticas, los eventos de colonización, los tiempos de divergencia y analizar el estado genético poblacional de las cuatro especies endémicas existentes en las Islas Galápagos. Encontramos que todas las especies representan grupos monofiléticos, que A. galapagoensis es la especie hermana de $A$. xanthaeolus del continente, y que estas dos especies son el grupo hermano del género Nesoryzomys. Nuestros resultados indican dos eventos de colonización en las islas. El primer evento muestra la llegada del ancestro de Nesoryzomys durante el Plioceno, siendo contemporáneo a la divergencia entre los dos géneros. El segundo evento de colonización ocurrió a mediados del Pleistoceno, cuando Aegialomys invadió el archipiélago y los eventos de diversificación de las especies comenzaron. En general, las poblaciones en las islas muestran una diversidad genética alta y una señal de expansión reciente. A pesar de ello, se requiere de más estudios para evaluar con precisión el estado de conservación de las poblaciones. Sugerimos que las poblaciones de estos roedores endémicos y vulnerables sean monitoreadas, realizando estudios ecológicos y genéticos. Adicionalmente, estudios futuros que utilicen marcadores moleculares distribuidos a través del genoma completo y que incluyan a las especies extintas en las islas y a más especies del continente, mejorarían el conocimiento sobre el origen y las relaciones de los roedores endémicos de las Islas Galápagos.

Key words: Aegialomys; colonization; diversification; Nesoryzomys; populations; speciation.

(C) 2019 Asociación Mexicana de Mastozoología, www.mastozoologiamexicana.org

\section{Introduction}

Remote oceanic islands and archipelagos are biologically simpler than continental regions and therefore provide ideal geographical and historical settings for the study of colonization, adaptation, speciation, and diversification of species. Islands have long been recognized as natural models for the study of evolutionary processes (Parent et al. 2008; Losos 2010; Rodrigues and Diniz-Filho 2016; RománPalacios and Wiens 2018). Compared to continental regions, islands are more ideal places to observe and interpret pat- 
terns of evolution due to their geographic isolation, small size, fewer numbers of species, and a high degree of endemism. The development of ecological and evolutionary systems can be directly observed on volcanic islands as we are now better able to date the timing of their emergence above the ocean surface as blank slates for colonization and the timing of subsequent evolutionary diversification (Losos and Ricklefs 2009; Hendriks et al. 2019).

The Galápagos Islands are a young oceanic and volcanic archipelago resulting from the eastward passage of the Nazca plate over a hotspot, at a rate of $59 \mathrm{~km} / \mathrm{My}$, located in the Pacific Ocean at approximately $960 \mathrm{~km}$ west of the coast of South America. It is composed of 13 major islands larger than $10 \mathrm{~km}^{2}$, six smaller islands, over 40 islets with official names and many smaller unnamed islets and rocks, for a total of approximately $8,000 \mathrm{~km}^{2}$ of land spread over 45,000 $\mathrm{km}^{2}$ of water (Snell et al. 1996; Parent et al. 2008, Geist et al. 2014, Harpp et al. 2014). The age of the islands increases moving eastward with the oldest islands located towards the southeast of the archipelago. The present islands date from up to 3.5 to 4 million years ago $(\mathrm{Ma})$ for the eastern islands of Española and San Cristóbal, respectively, to 60,000 years ago for Fernandina Island (Geist et al. 2014).

Despite their tropical climate, the Galápagos Islands have been the stage of surprisingly few animal diversifications compared with other Pacific tropical island groups. Among vertebrates, the absence of amphibians and the virtual absence of mammals are particularly striking and nearly unique among terrestrial island ecosystems (Parent et al. 2008). However, Román-Palacios and Wiens (2018) showed that the Galápagos archipelago drove faster rates of speciation and diversification in tanagers and tortoises, at least three times higher than in other related lineages of birds and tortoises inhabiting different islands.

The rodents of the Galápagos Islands are the only terrestrial mammals that have naturally colonized the islands and diversified within the archipelago. They belong to the Neotropical rice rat family Cricetidae, subfamily Sigmodontinae, tribe Oryzomyini. Two genera of rodents are currently known to be present on the islands: Aegialomys (Weksler et al. 2006) and Nesoryzomys (Heller 1904). There are two commonly recognized and described species in the genus Aegialomys: A. xanthaeolus the type species from the mainland and $A$. galapagoensis, formerly known from San Cristobal Island but has not been collected since their initial capture by Darwin in 1835 and is presumed extinct there (Patton and Hafner 1983; Dowler et al. 2000). In addition, the subspecies A. galapagoensis bauri, extant in Santa Fé Island, was previously considered a separate species but has been most often considered synonymous with A. galapagoensis (Cabrera 1961; Musser and Carleton 1993, 2005; Weksler et al. 2006; Weksler and Percequillo 2011; do Prado and Percequillo 2018). The genus Nesoryzomys comprises two extinct and three extant species. The two extinct species are $N$. indefessus from Santa Cruz and Baltra Islands and N. darwini from Santa Cruz Island. The extant species include N. swarthi from Santiago Island, and N. narboroughi and N. fernandinae from Fernandina Island (Dowler and Carroll 1996; Dowler et al. 2000). N. narboroughi has sometimes been synonymized with $N$. indefessus (Heller 1904; Musser and Carleton 1993, 2005), but in this manuscript we retain both $N$. indefessus and $N$. narboroughi as different species as recommended by Dowler (2015). The giant rice rat, Megaoryzomys curioi, is known only from subfossil remains from Santa Cruz Island and is not known to have a mainland representative (Patton and Hafner 1983). It is possible that its extinction occurred prior to human settlement of the archipelago.

To date, the only systematic study to include nearly all of the species in the Galápagos, both extinct and extant, is Patton and Hafner (1983). They did not analyze N. fernandinae (Hutterer and Hirsch 1980), which was described as a new species after their research was in press (Dowler et al. 2000). Based on a variety of data sets, including morphology, anatomy, protein electrophoresis and chromosome number and morphology, they suggested that: a) Nesoryzomys should be recognized at the generic level, nevertheless its origin is ambiguous, b) there were at least two independent colonizations of the islands, with Nesoryzomys representing an early arrival at 3 to $3.5 \mathrm{Ma}$, followed considerably later by Aegialomys as late as a few hundred to a thousand years ago, c) both Aegialomys taxa from the islands derived from $A$. xanthaeolus of the coastal Peruvian river valleys, d) $N$. narboroughi, N. swarthi and N. indefessus should be considered as races of a single species; and e) A. galapagoensis and $A$. bauri should be considered conspecific.

Dowler et al. (2000) performed one of the most recent field surveys during which they discovered a population of N. fernandinae; this allowed the first opportunity to describe the appearance of this species, which was previously known only from skeletal remains (Hutterer and Hirsch 1980) from Fernandina Island. They also found a viable population of N. swarthi on Santiago Island, which had previously been presumed extinct. These specimens represent the first endemic rodents taken on Santiago Island since the type series was collected in 1906 (Orr 1938), and a single partial skull was found in 1965 (Peterson 1966). However, recent molecular phylogenetic studies included only A. xanthaeolus, N. narboroughi and N. swarthi. Weksler $(2003,2006)$ and Weksler et al. (2006), using a nuclear exon and morphology, found that N. narboroughi and N. swarthi are monophyletic, and they are closely related to A. xanthaeolus. Pine et al. (2012), Leite et al. (2014), and Machado et al. (2014), using morphology and mitochondrial and nuclear genes, supported the results of Weksler $(2003, \underline{2006})$ and the results of Weksler et al. (2006).

Outside of what was learned from these studies, little is known about the endemic rodents of the Galápagos Islands; however, it is clear that they are critically threatened by invasive species and human activities. The goal of the present study was to undertake the first study including comprehensive sampling of all four extant endemic rodent 
species (A. galapagoensis, N. narboroughi, N. swarthi and N. fernandinae) inhabiting the archipelago, to provide a dated phylogeny, and to elucidate the population genetics status of each species. This information will help to elucidate the evolutionary history of these island taxa and synthesize information about evolution and biogeography at scales that span remote islands, archipelagoes and continents.

\section{Methods}

Sample collection. We obtained tissue samples (liver, kidney) from museum specimens deposited at Angelo State Natural History Collections (ASNHC) at Angelo State University and the Museum of Vertebrate Zoology at the University of California, Berkeley (MVZ). Additional samples were from ear biopsies from animals released at the collection site. We sampled 159 individuals of the Aegialomys and Nesoryzomys genera inhabiting the Galápagos Islands, $A$. galapagoensis $(n=43), N$. narboroughi $(n=49), N$. swarthi $(n$ $=43$ ), and N. fernandinae ( $n=24$; Figure 1, Appendix 1), and two samples of $A$. xanthaeolus from Ecuador to elucidate its relationship with $A$. galapagoensis. We used Pseudoryzomys simplex and Oligoryzomys microtis as outgroups for the phylogenetic analyses (sequences downloaded from GenBank, accession numbers AY863422.1 and AY863420.1, respectively).

DNA isolation and mitochondrial gene amplification. We extracted DNA from tissues using the DNeasy ${ }^{\circledR}$ Blood and Tissue Kit (QIAGEN, Inc., Valencia, CA) by cutting approximately $20 \mu \mathrm{g}$ of tissue into several small pieces and following the manufacturer's protocol. We amplified the mitochondrial control region (D-loop) by polymerase chain reaction (PCR) using the primers designed for Oligoryzomys spp. (González-Ittig et al. 2002). In rodents, the D-loop has been useful in phylogenetic analyses due to its elevated mutation rate, lack of recombination and maternal inheritance (Robins et al. 2014). Also, due to its high mutation rate, this marker has been used to detect signatures of population structure at a scale of just a few kilometers

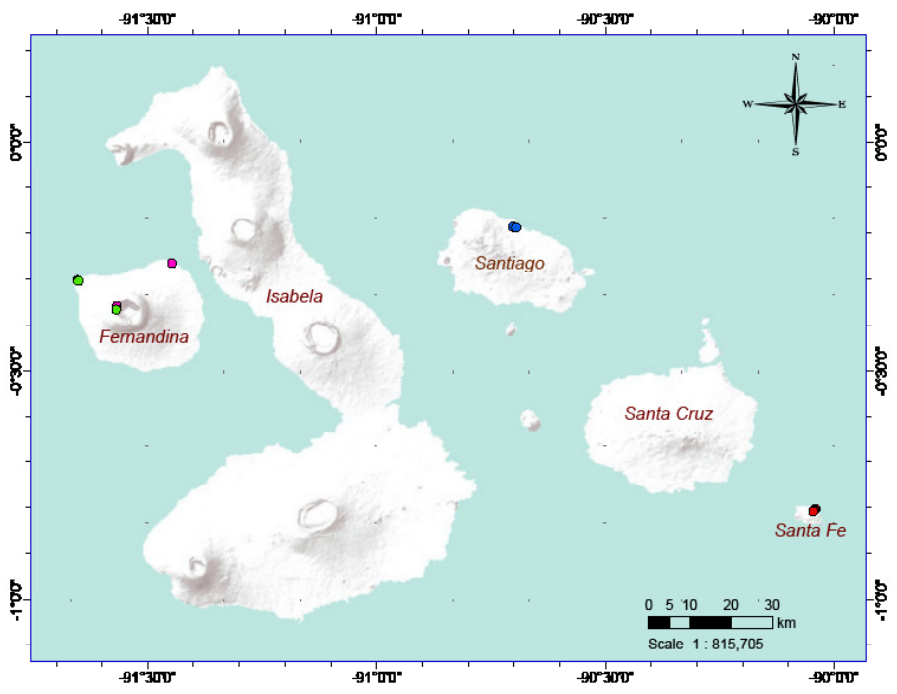

Figure 1. Sampling localities of $A$. galapagoensis (red dots; $n=43$ ), N. narboroughi (pink dots; $n=49$ ), N. swarthi (blue dots; $n=43$ ) and N. fernandinae (green dots; $n=24$ ) in the Galápagos Islands.
(Hirota et al. 2004; Urgoiti et al. 2018). The PCR reactions contained 14.85 $\mu \mathrm{L}$ DEPC H2O, $3.0 \mu \mathrm{L}$ 10X Reaction buffer, $3.0 \mu \mathrm{L}$ deoxynucleotide triphosphates (dNTPs, $2 \mathrm{mM}$ of each), $1.5 \mu \mathrm{L}$ each forward and reverse primer $(10 \mu \mathrm{M})$, $3.0 \mu \mathrm{L}$ of $0.1 \%$ bovine serum albumin (BSA), $0.15 \mu \mathrm{L}$ AmpliTaq DNA polymerase (Applied Biosystems, Foster City, CA), and $3 \mu \mathrm{L}$ of DNA for a final reaction volume of $30 \mu \mathrm{L}$. We used $1 \%$ agarose gels stained with ethidium bromide to visualize DNA extractions and to amplify products. Amplification parameters were as follows: initial step of $95^{\circ} \mathrm{C}(4$ min), followed by 34 cycles of denaturation at $95^{\circ} \mathrm{C}(40$ $\mathrm{sec})$, annealing at $50^{\circ} \mathrm{C}(30 \mathrm{sec})$, extension at $72^{\circ} \mathrm{C}(90 \mathrm{sec})$, and a final extension at $72{ }^{\circ} \mathrm{C}(10 \mathrm{~min})$. Reaction products were purified using AMPure Magnetic Beads (Agencourt Bioscience, Beverly, MA). The Oligoryzomys D-loop primers were used in an initial sequencing run. More specific internal forward and reverse primers were designed using the sequence fragments obtained from this initial run. The internal primers GIF (5' - CCACTACCAGCACCCAAAGCTG - 3') and GIREV (5'- GGTTGTGTTGATTAATGATCC - 3') were used in all sequencing reactions. Five microliters of cleaned PCR product were added to $4 \mu \mathrm{L}$ of ABI Prism Big Dye Terminator Cycle Sequencing Ready Reaction Kit (Applied Biosystems, Foster City, CA) and 1.0 $\mu \mathrm{L}$ of $1.6 \mu \mathrm{M}$ internal primer in each sequencing reaction (GIF and GIFREV). Sequencing reaction conditions were: $96^{\circ} \mathrm{C}(1 \mathrm{~min}), 45$ cycles of $96^{\circ} \mathrm{C}(30$ $\mathrm{sec}), 58^{\circ} \mathrm{C}$ for GIF or $52^{\circ} \mathrm{C}$ for GIREV ( $\left.15 \mathrm{sec}\right), 60^{\circ} \mathrm{C}(4 \mathrm{~min})$, followed by a final holding step of $4^{\circ} \mathrm{C}$. All sequencing reactions were performed using GeneAmp ${ }^{\circledR}$ PCR System 9700 (Applied Biosystems, Foster City, CA). Final sequencing products were purified using Sephadex G-50 powder then dried in a vacuum centrifuge and stored at $-20^{\circ} \mathrm{C}$. Sequences were re-hydrated with the addition of $5 \mu \mathrm{L}$ of HiDi Formamide with $0.1 \mathrm{mM}$ EDTA, denatured at $95^{\circ} \mathrm{C}(3$ min) and sequenced with capillary action electrophoresis using SCE 9610 Genetic Analysis System (SpectruMedix, State College, PA).

Phylogenetic analyses and divergence times estimation. We cleaned and edited sequences using Geneious ${ }^{\circledR}$ 11.1.4 (https://www.geneious.com), and performed multiple sequence alignment using ClustalW v.2.1 (Larkin et al. 2007) implemented in Geneious. The best evolutionary model of nucleotide substitution was estimated in jModelTest 2.1.1 (Guindon and Gascuel 2003; Darriba et al. 2012) using the Akaike information criterion. A Bayesian Inference (BI) analysis was performed in MrBayes 3.2.6 (Huelsenbeck and Ronquist 2001; Ronquist and Huelsenbeck 2003), run for 20 million generations sampling every 1,000 generations. Output parameters were visualized using Tracer v1.7.1 (Rambaut et al. 2018) to check for convergence between runs, and the first $25 \%$ of the trees were discarded as burn-in.

We used BEAST v2.5.2 (Bouckaert et al. 2014) to estimate molecular dates of divergences under an uncorrelated lognormal relaxed molecular clock model. The time to the most recent common ancestor for the main lineages was obtained using Bayesian Markov chain Monte Carlo 
(MCMC) searches. We sampled trees and divergence dates for all nodes every 10,000 iterations for 50,000,000 generations. These analyses implemented the Yule speciation processes model and the randomly generated starting tree as priors. We used three calibration points. The first calibration was based on a biogeographical event: the origin of the Galápagos archipelago at 5 Ma (Geist et al. 2014). Machado et al. (2014) found that the lineage leading to the endemic genus Nesoryzomys derived from an ancestor shared with the clade composed of Melanomys, Sigmodontomys and Aegialomys and split around 1.49 (95\% HPD : 0.26 to 3.23) Ma. We used the split between Nesoryzomys and Aegialomys as a second calibration point. The third calibration point was based on the split of the lineage leading to Pseudoryzomys around 2.58 (95\% HPD : 0.43 to 5.38) Ma (Machado et al. 2014). We checked convergence statistics for effective sample sizes using Tracer v1.7.1 (Rambaut et al. 2018). We used TreeAnnotator v2.5.2 (available in the BEAST package) to get a consensus tree with node height distribution after elimination of $25 \%$ of trees as burn-in. We visualized MrBayes and Beast results using FigTree v1.4.2 (http://tree.bio.ed.ac.uk/software/figtree/).

We performed $\mathrm{BI}$ and Beast analyses including all samples per species (trees not shown). We chose to perform the phylogenetic and dating analyses using representative samples of each species to reduce the saturation effects. Populations-level analyses included all the samples.

Population analyses. We conducted population genetic analyses separately for each clade determined with the $\mathrm{BI}$ analysis, with the exception of $A$. xanthaeolus because of the small sample size. The number of haplotypes $(H)$, nucleotide diversity $(\pi)$ (Nei 1987), haplotypic diversity (h), number of polymorphic segregating sites $(S)$, singletons $\left(S_{1}\right)$, parsimony informative sites (PIS), and the average number of nucleotide differences $(K)$ were estimated using DNAsp v6.12 (Rozas et al. 2017). We performed Fu's Fs (Fu 1997) and Tajima's D (Tajima 1989a) neutrality tests to evaluate whether data departed from a neutral model of evolution due to factors such as population bottleneck or sudden expansion. Statistical significance was determined using the coalescent simulator in DNAsp v6.12 (Rozas et al. 2017) with 1000 simulations.

We used the distribution of the number of pairwise mutational differences among individuals, or mismatch distribution, to explore demographic patterns of populations using DNAsp v6.12 (Rozas et al. 2017); graphical representation was made by means of the growth-decline model. Raggedness ( $r$ ) index (Harpending 1994) and $R_{2}$ statistics of Ramos-Onsins and Rozas (2002) were calculated to analyze goodness of fit of a population expansion model using 1000 simulations in the same program. Populations at demographic equilibrium or in decline should provide a multimodal distribution of pairwise differences, whereas populations that have experienced a sudden demographic expansion should display a star-shaped phylogeny and a unimodal distribution (Tajima 1989b; Slatkin and Hudson
1991; Rogers and Harpending 1992; Harpending and Rogers 2000). However, recent changes in population size may not be detectable in mismatch distribution analyses due to threshold effects, time lags, or earlier demographic events that may mask the effects of recent events (Rogers and Harpending 1992; Harpending and Rogers 2000).

We analyzed the magnitude of historical demographic events by constructing Bayesian Skyline Plots (BSP) using BEAST v2.5.2 (Bouckaert et al. 2014). This analysis infers population fluctuations over time by estimating the posterior distribution of the effective population size at specific intervals along a phylogeny (Drummond and Rambaut 2007). Genealogies and model parameters were sampled every 10,000 iterations along $50,000,000$ generations under a relaxed molecular clock, with $25 \%$ of burn-in. Convergence statistics for effective sample sizes and demographic plots were visualized using Tracer v1.7.1 (Rambaut et al. 2018). In comparison with simple parametric and older coalescent demographic methods, the smoother estimates and sensitivity of this method, together with credibility intervals, provide a realistic population size function and enable retrieval of more details than just summary statistics (Deli et al. 2016).

To further investigate the genetic relationships of the haplotypes at the intraspecific level we constructed haplotype networks using the Median-Joining algorithm (Bandelt et al. 1999) implemented in PopART v1.7 (Leigh and Bryant 2015).

\section{Results}

Phylogenetic lineages and divergence time. We amplified an average of $643 \mathrm{bp}$ of the D-loop gene from 159 individuals of the Aegialomys and Nesoryzomys genera inhabiting the Galápagos Islands (A. galapagoensis $n=43, N$. narboroughi $n=49$, $N$. swarthi $n=43$, and $N$. fernandinae $n=24$, Figure 1, Appendix 1) and two samples of $A$. xathaeolus from the mainland.

The TVM with gamma distribution $(+G)$ model was recognized as the best fitting model with the following parameters: base frequencies $A=0.3612, C=0.2445, G=$ $0.1109, \mathrm{~T}=0.2834$; nst $=6$; and rates $=$ gamma with shape parameter $(\alpha)=0.6020$. The BI and Beast analyses including all the samples per species (trees not shown) confirmed the monophyly of each of the species. However, the relationship with the outgroups was not well resolved and the posterior probabilities were lower. This could be due to the high mutation rates that are inherent to the $D$ - loop region which can result in genetic saturation. Distantly related taxa are often affected by saturation effects. When sequences in a multiple alignment have undergone multiple substitutions, the apparent distances largely underestimate the real genetic distances and the alignment is said to be saturated (Philippe et al. 2011). In phylogenetics, saturation effects result in long branch attraction, decrease of phylogenetic information, and underestimation of observed divergence times (Wilke et al. 2009, Philippe et al. 2011). We thus focused our subsequent results and conclusions on the 
analyses that included only representative samples of each species. The $\mathrm{BI}$ analyses showed a topology in which four main clades for the Galápagos species were recognized with high levels of support and one clade including the continental species (Figure 2). All of the Galápagos rodent species analyzed were monophyletic. Clade 1 corresponds to all individuals recognized as $A$. xanthaeolus, which is a sister group of Clade 2, which includes all representatives of A. galapagoensis. Clade 3 corresponds to all samples identified as N. narboroughi, which is the sister to Clade 4 and Clade 5, corresponding to N. swarthi, and N. fernandinae, respectively.

The analysis estimating the time to the most recent common ancestor (TMRCA) showed that the oldest divergence event corresponds at the split between the Nesoryzomys and Aegialomys genera, dated around 3.84 (95\% HPD : 2.91 - 4.88) Ma (Figure 3). The first split between a continental versus an island species, $A$. xanthaeolus and A. galapagoensis, occurred around 1.11 (95\% HPD : 0.37 to 2.11) Ma. Speciation within the genus Nesoryzomys started around 2.23 (95\% HPD : 1.32 to 3.12) Ma with the split between N. fernandinae and N. swarthi versus N. narboroughi, followed by the split between the two lineages composed of N. fernandinae and N. swarthi which occurred around 1.58 (95\% HPD : 0.91 to 2.42) Ma. The estimated dates of divergence for the main nodes and their highest posterior density values are shown in Table 1. According to these results, the main speciation events occurred since the early-middle Pliocene up to the Pleistocene. However, the diversification within each species started at the end of the Pleistocene around 525,500 years ago.

Demographic reconstruction. Genetic diversity and neutrality test per species are shown in Table 2 . All of the endemic species of the Galápagos Islands showed high genetic diversity $(H d>0.965)$. N. fernandinae has the highest number of unique haplotypes in proportion with the number of samples, and $N$. swarthi the lowest.

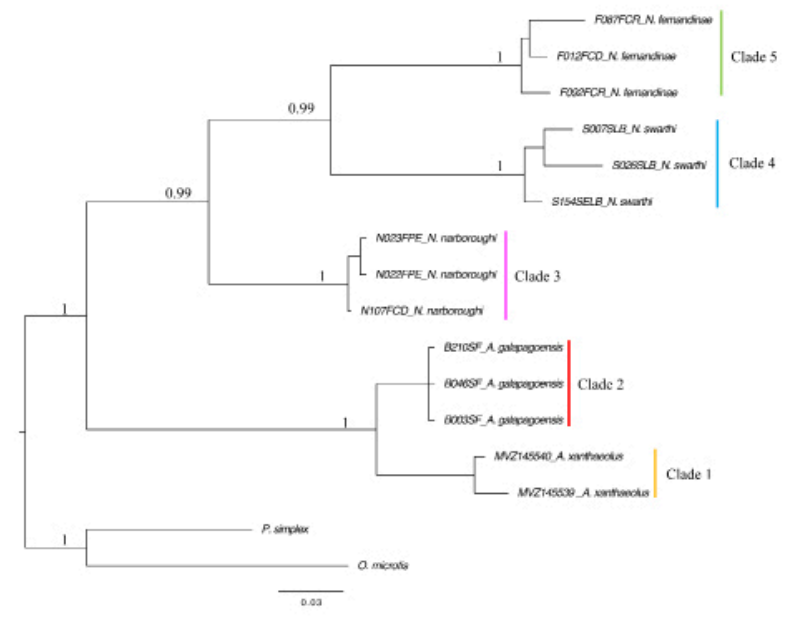

Figure 2. Phylogenetic tree of the four extant endemic rodents of the Galápagos Islands based on Bayesian Inference analysis of mtDNA D-loop sequence data. Numbers at nodes indicate support values of posterior probabilities.
Table 1. Estimated dates of divergence (time to the most recent common ancestor - TMRCA - and $95 \%$ High Posterior Density confidence intervals - HPD - in Ma) for the extant species within the Nesoryzomys and Aegialomys genera. Clades depicted by letters correspond to those indicated in Figure 2.

\begin{tabular}{ccc}
\hline Clade & TMRCA & $95 \%$ HPD \\
\hline A & 4.26 & $3.01-5.63$ \\
B & 3.84 & $2.91-4.88$ \\
C & 2.44 & $0.72-4.01$ \\
D & 2.23 & $1.32-3.12$ \\
E & 1.58 & $0.91-2.42$ \\
F & 1.11 & $0.37-2.11$ \\
G & 0.52 & $0.21-0.95$ \\
H & 0.45 & $0.14-0.84$ \\
I & 0.26 & $0.03-0.58$ \\
J & 0.16 & $0.02-0.41$ \\
K & 0.11 & $0.01-0.27$ \\
\hline
\end{tabular}

The applied neutrality test revealed significant deviations from mutation-drift equilibrium for all the species inhabiting Galápagos according to Fu's $F_{s}$ values, and only for A. galapagoensis using Tajima's $D$. The negative values suggest recent population expansion events in these species (Table 2).

The statistical analyses of mismatch distribution showed unimodal distributions for A. galapagoensis, N. narboroughi and $N$. fernandinae, which also suggests a recent demographic expansion (Slatkin and Hudson 1991, Rogers and Harpending 1992) or spatial expansion (Ray et al. 2003, Excoffier 2004). Statistical analysis of the mismatch distribution $r$ index and $R_{2}$ were significant (Figure 4).

The Bayesian skyline demographic reconstructions showed a pattern of constant size of populations through time, followed by a recent and small increase (Figure 5). $A$. galapagoensis and $N$. fernandinae show a small growth period, which started around 10,000 and 13,000 years ago, respectively. N. narboroughi and $N$. swarthi show a more constant trend of population increase, starting around 50,000 and 90,000 years ago, with a rapid increase starting around

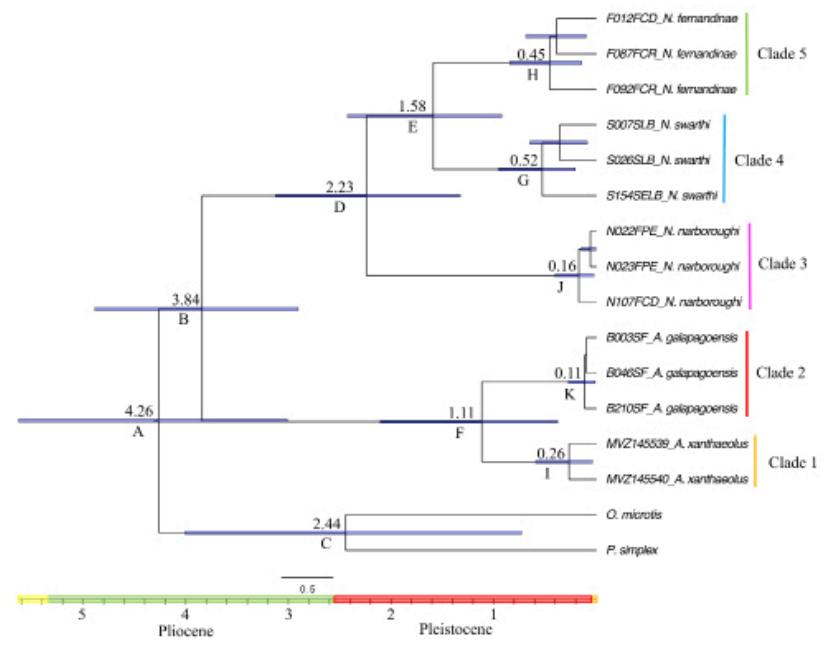

Figure 3. Dated phylogeny of the extant endemic rodents of the Galápagos Islands reconstructed from mtDNA D-loop haplotypes inferred from BEAST. The horizontal bars show the $95 \%$ confidence intervals. Time-scale in millions of years ago. Dates and letters at nodes depict values calculated in Table 1. 

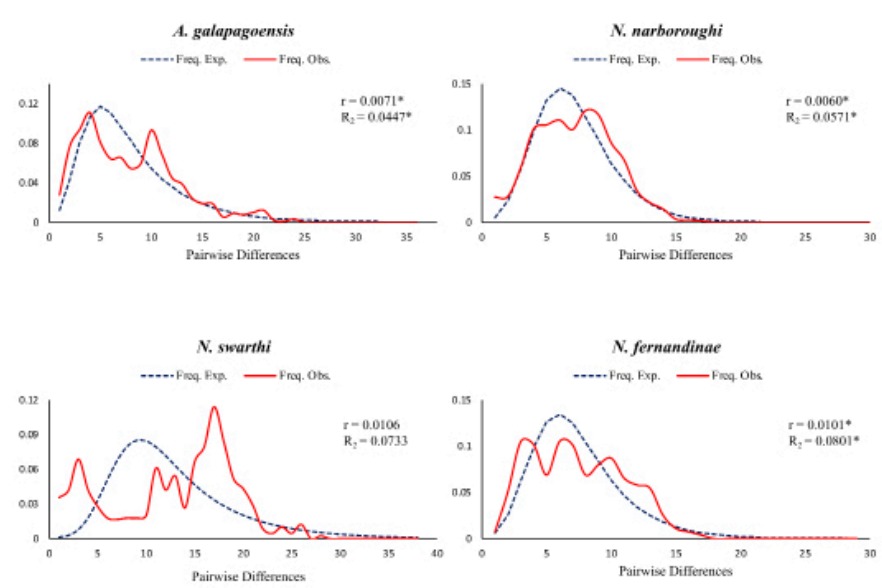

Figure 4. Mismatch distribution of pairwise differences of haplotypes for each of the extant species inhabiting the Galápagos Islands. Shown are observed (red lines) and expected (dark blue square dot lines) frequencies obtained under a model allowing for population size change. Raggedness $(r)$ index and $R_{2}$ statistics values are shown. Significance is indicated with a star $\left(^{*}\right)$.

6,000 and 25,000 years ago, respectively. Skyline reconstruction showed that A. galapagoensis, N. narboroughi, N. swarthi and $N$. fernandinae have similar populations sizes.

Overall, the network analyses including all haplotypes for each species show a few abundant haplotypes, with frequencies between two and six, and numerous unique ones for all the species (Figure 6). N. fernandinae showed more unique haplotypes, with two being the highest frequency observed for a haplotype. The four species show long branches with haplotypes that are highly differentiated from the other haplotypes. N. narboroughi and N. fernandinae, for which samples were collected from three and two localities in Fernandina Island, respectively, do not show that the distribution of the haplotypes follows any structure or differentiation. Only N. narboroughi has two shared haplotypes among localities. Though A. galapagoensis and N. narboroughi do not show networks with a star-like shape, both networks show haplotypes with many connections, suggesting recent populations or with recent demographic expansion. In contrast, the networks of $N$. swarthi and $N$. fernandinae may suggest older or more stable populations.

\section{Discussion}

This is the first genetic study to include all extant endemic rodent species of the Galápagos Islands. We implemented different genetic analyses in order to elucidate the phylogenetic relationships among these rodents inhabiting the
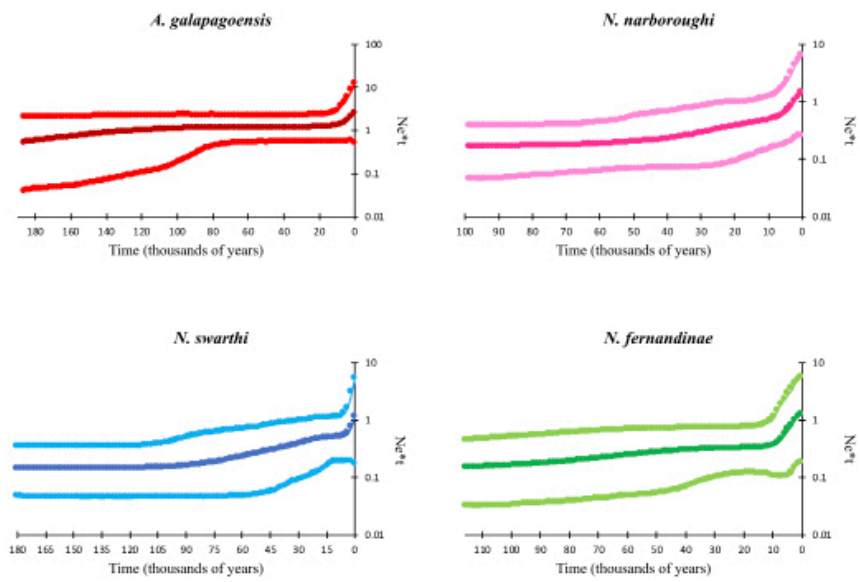

Figure 5. Skyline plots for each extant species of rodents inhabiting the Galápagos Islands. Plots show posterior median (darker lines) and $95 \%$ Bayesian credible intervals (lighter lines on the outside) of the effective population size. The Y axis is in logarithm scale.

archipelago, as well as demographic history and relationships of their populations. This information is extremely important for conservation of these endemic species, given that there is very little known about their biology and ecology, and that they are considered vulnerable, mainly due to human activities and the introduction of invasive species. Furthermore, we contributed phylogenetic and demographic information as well as divergence estimates in order to form hypotheses regarding colonization of the islands and compare them with previous hypotheses.

Our phylogenetic study corroborated the monophyly of the genera Aegialomys and Nesoryzomys as Patton and Hafner (1983) and Weksler (2003, 2006), proposed. However, those authors did not include all the extant species. We also corroborated the monophyly of the continental species $A$. xanthaeolus and the island species $A$. galapagoensis, N. naboroughi, N. swarthi and N. fernandinae. Our calibration results suggest that the main speciation events started during the Pliocene with the split between the genus Aegialomys and Nesoryzomys (3.84 Ma, $95 \%$ HPD:2.9 to 4.88), which agrees with the time proposed by Patton and Hafner (1983), using Nei's methods, dated around 3 to 3.5 Ma; it differs from that proposed by Machado et al. (2014), dated around $1.49 \mathrm{Ma}$ (95\% HDP:0.26 to 3.23), and Parada et al. (2013) around 2.4 Ma (95\% HDP not available) during the Pleistocene. The difference between Machado et al.'s estimate and ours could be due to the genes used; they used IRBP and Cyt b, while we used D - loop. Also, despite the fact that our study and Machado et al.'s both used the

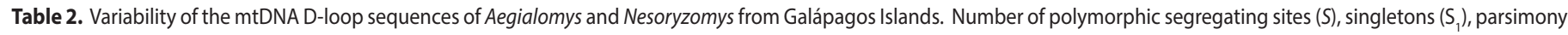
informative sites (PIS), haplotype diversity $(H d)$, nucleotide diversity $(\pi)$, and average number of nucleotide differences $(K)$. Significance is indicated with a star $(*)$.

\begin{tabular}{|c|c|c|c|c|c|c|c|c|c|c|c|}
\hline Species & $\begin{array}{c}\text { Total } \\
\text { basepairs }\end{array}$ & $\begin{array}{c}\text { Number of } \\
\text { samples }\end{array}$ & $\begin{array}{l}\text { Number of } \\
\text { haplotypes }\end{array}$ & $s$ & $\mathbf{S}_{1}$ & PIS & Hd & $\pi$ & $K$ & Fu's $F_{s}$ & Tajimas'D \\
\hline Aegialomys galapagoensis & 652 & 43 & 29 & 70 & 46 & 24 & $0.972 \mp 0.012$ & $0.01298 \mp 0.0017$ & 6.970 & $-14.570^{*}$ & $-2.18653^{*}$ \\
\hline Nesoryzomys narboroughi & 711 & 49 & 32 & 48 & 27 & 21 & $0.973 \mp 0.011$ & $0.01003 \mp 0.0006$ & 6.179 & $-19.085^{*}$ & -1.50303 \\
\hline Nesoryzomys swarthi & 629 & 43 & 30 & 71 & 42 & 29 & $0.965 \mp 0.016$ & $0.02130 \mp 0.0012$ & 11.817 & $-8.969 *$ & 1.20756 \\
\hline Nesoryzomys fernandinae & 578 & 24 & 22 & 33 & 15 & 18 & $0.993 \mp 0.014$ & $0.01204 \mp 0.0015$ & 6.467 & $-15.631^{*}$ & -1.39461 \\
\hline
\end{tabular}



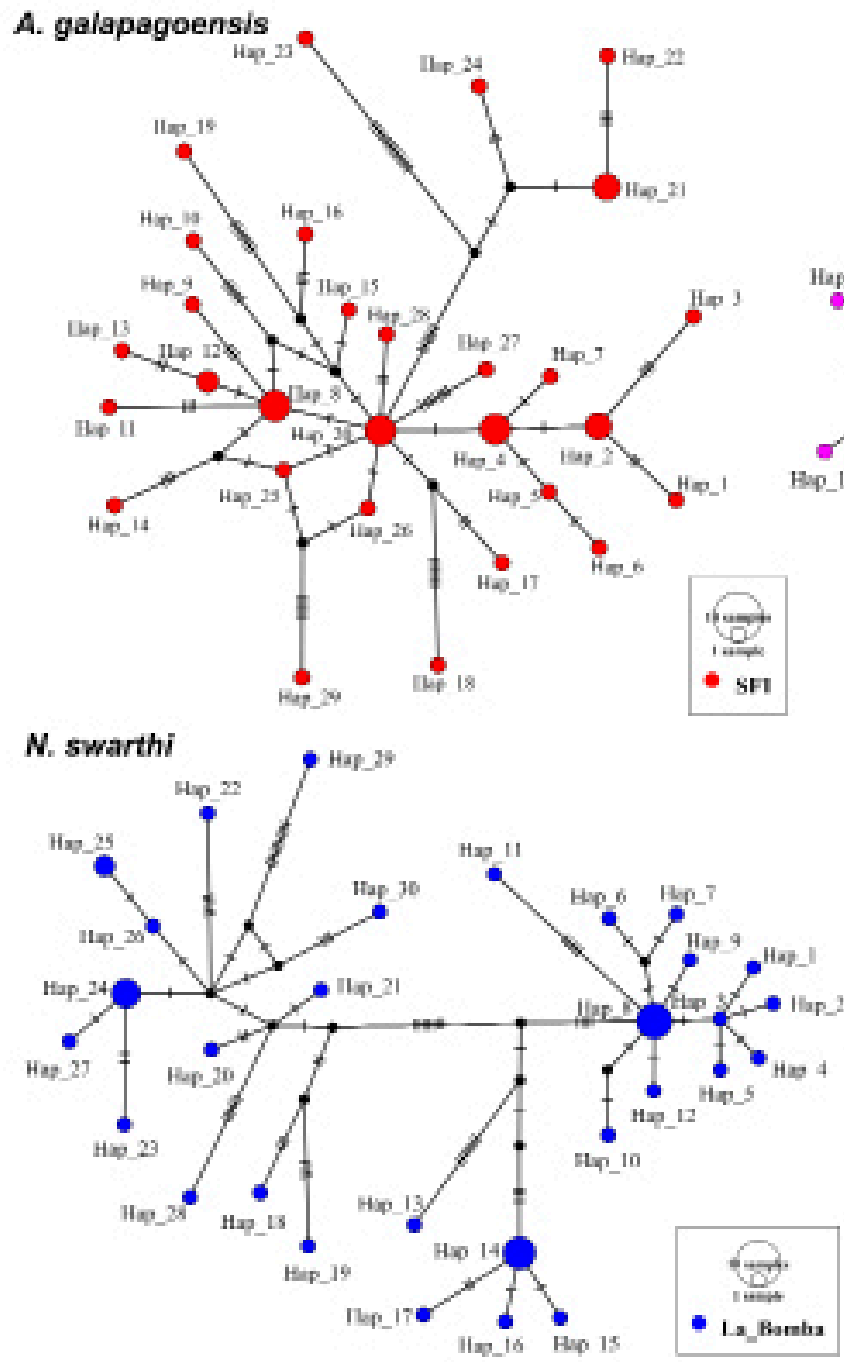

N. narboroughi

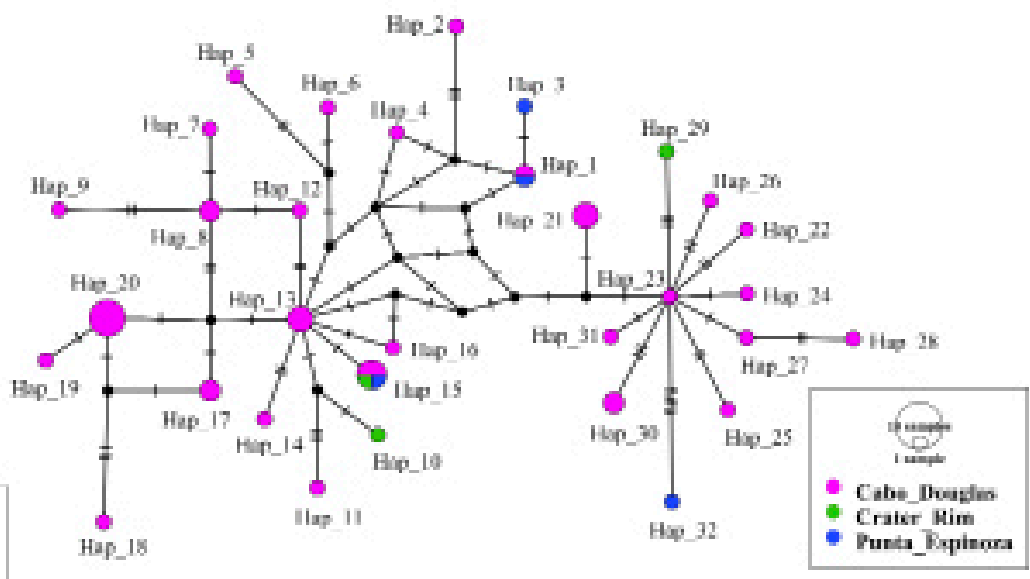

N. fernandinae

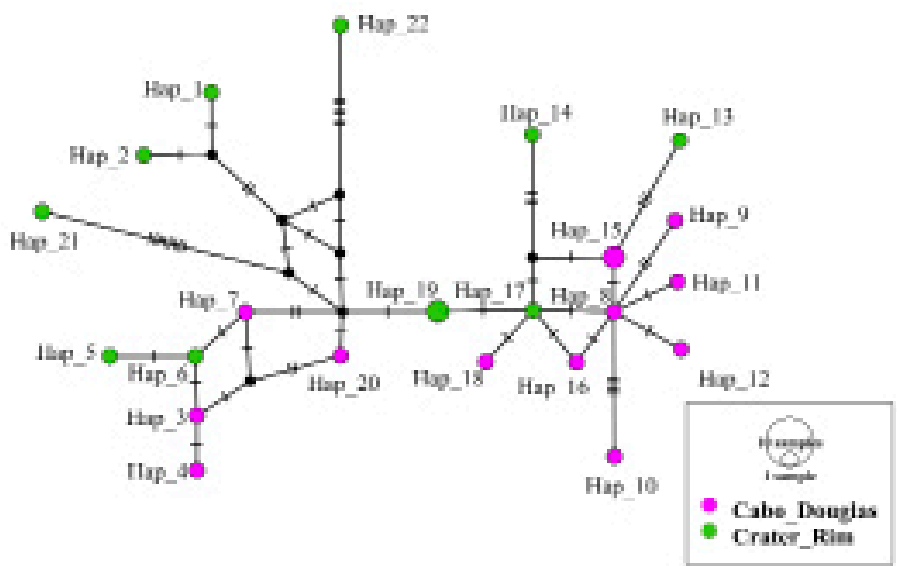

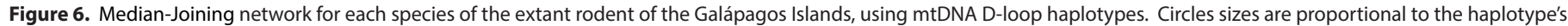
frequencies in the population. The lines along the branches connecting the haplotypes show the number of substitutions.

origin of the Galápagos as a calibration point, we used the new date proposed by Geist et al. (2014) of $5 \mathrm{Ma}$, while Machado et al. used $4 \mathrm{Ma}$ (Geist 1984). We also included $A$. galapagoensis from the islands, while they only used $A$. xanthaeolus. Including the two species of the genus Aegialomys, and specifying an older date for the origin of the archipelago, resulted in an older date for the split between these genera, which is well supported with the paleogeographic and biogeographical information. Despite this discrepancy, there is substantial overlap in the credibility intervals of these two assessments.

The second major speciation event occurred within the genus Nesoryzomys with the split between $N$. narboroughi versus $N$. swarthi and $N$. fernandinae dated at 2.23 Ma (95 \% HDP:1.32 to 3.12) during the Pleistocene. Leite et al. (2014) dated the split between N. narboroughi and N. swarthi around $2 \mathrm{Ma}$ (95\% HDP not available) during the Pleistocene, supporting our results. The third major event occurred at $1.58 \mathrm{Ma}$ (95\% HDP:0.91 to 2.42) during the Pleistocene with the split between N. swarthi and N. fernandinae. Finally, the speciation between $A$. xanthaeolus and $A$. galapagoensis occurred at $1.11 \mathrm{Ma}$ (95\% HDP: 0.37 to 2.10 ), also during the Pleistocene.

Rice rats are the only terrestrial mammals that naturally colonized the Galápagos and diversified within the archipelago (Clark 1984, Parent et al. 2008). There are some prior hypotheses about how these two genera colonized islands. Patton and Hafner (1983) suggested that Nesoryzomys is an old immigrant to the islands while the Aegialomys species is quite recent. They based their results on the high degree of morphological and biochemical (allozyme) distinctiveness of Nesoryzomys relative to other oryzomyines, including Aegialomys. This supported a more ancient origin and a single immigration to the islands, whether of pre-Nesoryzomys or Nesoryzomys form with subsequent radiation within the islands. In contrast $A$. galapagoensis is nearly morphological identical to the mainland $A$. xanthaeolus, which suggests an introduction to the islands within the last few hundred to thousand years, perhaps via pre-Columbian humans coursing the west coast of Perú (Patton 1984; Pine et al. 2012). Parent et al. (2008) suggested that colonization events on the Galápagos occurred over the last 3 to 4 Ma during the existence of the present islands, and might have happened earlier when now sunken islands were above sea level. The 
presence of several drowned seamounts on the Carnegie Ridge east of the Galápagos (Christie et al. 1992) suggests that earlier volcanic islands may have served as stepping stones for colonization by some of the terrestrial fauna. Parent et al. (2008) also mentioned that rice rat diversity is the result of one colonization event from the South American continent, where their close relatives inhabit, as it has been shown in other species of tortoises and lizards (i. e., Caccone et al. 1999; Kizirian et al. 2004; Benavides et al. 2007).

Our results suggest two colonization events to the Galápagos by the extant species. The first arrival by the ancestor of Nesoryzomys was probably a species of Sigmodontomys or Melanomys that originated from lower montane and lowland forest habitats in South America (Harris and Macdonald 2007). This event should be dated from the early-late Pliocene boundary onwards, as proposed by Leite et al. (2014). This was followed by a second arrival of Aegialomys from coastal Perú by rafting over recent historical times to the middle Pleistocene, giving rise to the Aegialomys of the Galápagos (Patton 1975; Steadman 1985; Hutterer and Oromí 1993; Weksler 2003). It is well known that these species, and the most closely related ones, are excellent dispersers across salt water (Pine et al. 2012), making colonization easier for them.

The fauna and flora of the Galápagos Islands is principally derived from western South America, Central America, and the Caribbean (Merlen 2014). So, we assume that colonization from there to the archipelago during the Pliocene was possible because there is strong evidence (Christie et al. 1992; Werner et al. 1999) that islands have been forming over the hotspot for at least twice as long as the age of the oldest islands, and perhaps as long as $20 \mathrm{Ma}$. These ancient islands are now seamounts east of the present-day Galápagos along the Carnegie Ridge on the Nazca Plate (Christie et al. 1992) and northeast of the archipelago on the Cocos Plate on the Cocos Ridge (Werner et al. 1999). There has been a "conveyor belt" of islands produced over millions of years, providing the potential for organic colonization during that time (Merlen 2014).

Once the ancestors of Nesoryzomys and Aegialomys arrived to the Galápagos Islands, dispersal, colonization, speciation, and diversification were possible during the Pleistocene, in part, because the integrated area of the Galápagos Islands was much greater than today, land bridges existed between a few of the major islands, and many more minor islands and islets were exposed. In fact, there is a hypothesis that between 1 and $5 \mathrm{Ma}$, at least nineteen major Galápagos Islands existed but are currently submerged; these are in addition to the thirteen that exist today (Geist et al. 2014). Later island fragmentation has led to diversification by vicariance as well as dispersal. Dispersal was also possible because the main part of the Galápagos lies in shallow water created by the broad Galápagos platform, which formed by the accumulation of lavas (Geist et al. 2008).

Aegialomys galapagoensis, the Galápagos rice rat, is only found in one population on Santa Fé Island and is the lat- est species to have colonized the archipelago. Our results show high genetic diversity for the species and a signal of recent expansion. This finding is consistent with the fact that A. galapagoensis and N. narboroughi have been considered common by virtually all researchers visiting the islands (Clark 1980; Patton and Hafner 1983; Clark 1984; Key and Muñoz-Heredia 1994). In fact, Dowler et al. (2000) reported that the species was abundant and rice rats could be seen running among the lava rocks before dark. Another reason is that both Santa Fé Island and Fernandina Island are the only two islands that do not have introduced species of rats and mice (Dowler et al. 2000), allowing the persistence of the native species. This species is considered vulnerable by the Red List of the International Union for Conservation of Nature (IUCN 2019). We dated the events of speciation and diversification to around $1.11 \mathrm{Ma}$ and 111,200 years ago, respectively; both of them occurred after the emergence of Santa Fé Island, dated at 2.9 Ma (Geist et al. 2014). Clark (1980) conducted an ecological study and found that A. galapagoensis has high survival and low reproduction relative to congeners of other geographic areas. He did not know if this strategy was specific to A. galapagoensis or a common feature of the Galápagos rodent life history (Harris and Macdonald 2007).

Nesoryzomys narboroughi, the large Fernandina rice rat, is only found on Fernandina Island. It is the oldest species within the extant rodents of Galápagos, with a speciation event dated at $2.23 \mathrm{Ma}$; however, its diversification is the most recent among the extant Nesoryzomys, starting around 169,400 years ago. This species is considered vulnerable according to the Red List (IUCN 2019); however, Dowler et al. (2000) verified the presence of sustainable populations, which are found from the coastline to the volcano rim. We found that the genetic diversity of this species is high, and their populations are under recent expansion. This could be due to the fact that Fernandina Island does not have introduced species of rats and mice, allowing the persistence of $N$. narboroughi.

Nesoryzomys fernandinae, the small Fernandina rice rat, is also found on Fernandina Island in sympatry with N. narboroughi (Hutterer and Hirsch 1980; Dowler et al. 2000). Its populations range from the coast up to the volcano rim. Dowler et al. (2000) found that this species is more abundant at high elevations along the volcano rim, where vegetation, primarily Scalasia spp., is most dense. Meanwhile, $N$. narboroughi is more abundant near the coast, suggesting that the species distributions are influenced by habitat (Dowler and Carroll 1996). N. fernandinae was considered extinct (IUCN 1996; Nowak 1999), but now its status is vulnerable according to the Red List (IUCN 2019). This species has the highest genetic diversity within the genus, and it shows a more stable population in comparison with $N$. narboroughi, which showed recent expansion. We dated the events of speciation and diversification to $1.58 \mathrm{Ma}$ and 452,900 years ago, respectively. The presence of $N$. narboroughi and N. fernandinae on Fernandina Island suggest that 
volcanic activity has not occurred on an island-wide scale sufficient to destroy their populations as Merlen (2014) suggested. He also proposed that Fernandina Island is a refuge for biodiversity in Galápagos based on the formation of endemic species, the establishment of terrestrial ecosystems at several altitudes, and climate conditions.

Fernandina Island has the most active volcano and is the youngest major island in the archipelago. Its emergence is suggested to have occurred approximately 32,000 years ago with a maximum emergence around 60,000 years ago (Geist et al. 2014). The dates that we obtained for the speciation and diversification of N. narboroughi and N. fernandinae are older than the dates proposed for the origin of the island.

Nesoryzomys swarthi, the Santiago Galápagos mouse, is endemic to Santiago Island where it exists as a single population in the arid zone of the north-central coast (Dowler et al. 2000; Harris et al. 2006). This species coexists with Rattus rattus and Mus musculus on the island. However, the three species are only sympatric near the beach, where the densities of the invasive species are lower (Dowler et al. 2000; Harris et al. 2006). Brosset (1963) considered that $N$. swarthi was extinct based on the introduction of diseases or parasites by invasive species, and/or competition with them. At present, it is considered vulnerable according to the Red List (IUCN 2019). Our results showed that the species has relatively high genetic diversity, despite being the lowest genetic diversity among the other native rodents. Two of our analyses show a signal of recent expansion, but one of them rejected this hypothesis. We consider that more genetic analyses, including more loci, are necessary to resolve this discrepancy. It is possible that the species underwent a recent bottleneck; however, the genetic signal is not strong. A bottleneck event in the species would be consistent with the fact that it was considered extinct for decades while it went undetected until Dowler et al. 2000 rediscovered it. However, we do not have enough data to thoroughly test this hypothesis. The emergence of Santiago Island has been dated to a minimum of 800,000 years ago and a maximum of $1.4 \mathrm{Ma}$, which agrees with the time of speciation and diversification that we found for N. swarthi around $1.58 \mathrm{Ma}$ and 525,500 years ago, respectively. Harris and Macdonald (2007) performed an ecological study and found that the unpredictable environment of the Galápagos arid zone has selected for a strategy of high survivorship and low reproduction in N. swarthi that is more typically found among desert Heteromyidae than other members of the Oryzomyini. Clark (1980) found the same result in A. galapagoensis. It seems that this strategy is a common feature of native rodents of the Galápagos Islands.

According to our results, we have two main conclusions. The first is that populations of the extant rodents on the Galápagos show high genetic diversity and most show a signal of recent expansion. Despite the challenges that are faced by these species by the extreme arid conditions on the islands, the impact of human activities, and the pres- ence of invasive species, our results suggest that these species do not have genetic signatures implying that they have experienced dramatic population declines and, rather, that populations are demographically stable. However, based on previous studies this conclusion should be considered carefully. For example, the desert-adapted life histories of these species are impressive because their ancestors were not well adapted to dry environments and oryzomyine rodents of semiarid habitats often lack the physiological adaptations to xeric conditions (Best 1988; Meserve 1978; Ribeiro et al. 2004; Harris and Macdonald 2007). Moreover, the fact that the abundance of these endemic rodents is positively related to vegetation density suggests that the presence of these species is resource-limited (Clark 1980; Dowler and Carroll 1996; Harris and Macdonald 2007). This could explain why some native species can coexist with invasive species or coexist in sympatry with other native species if there are enough resources to minimize competition. In this sense, there is now evidence that introduced rodents may not be the sole cause of decline in native rodents in Galápagos; feral cats may be a second important factor in rodent decline and extinction (Dowler et al. 2000; Dexter et al. 2004), as well as loss of habitat and resources or the introduction of pathogens. In light of these previous findings and our results, we should continue to monitor these vulnerable species, performing more fine-scale ecological and population studies in the future.

Our second major conclusion is that the major speciation events of the four extant rice rats occurred within the archipelago during the Pleistocene. In the case of A. galapagoensis and N. swarthi, their diversification occurred on Santa Fé and Santiago Islands, respectively, and their speciation likely occurred within their current range. However, for the species inhabiting Fernandina Island, N. narboroughi and N. fernandinae, speciation and diversification likely occurred on a different island, because Fernandina Island is younger than these events. We hypothesize that after speciation on a different island, they dispersed to Fernandina Island. Isabela Island is the largest within the archipelago, and it is close to Fernandina. Its emergence is dated to around 500,000 to 800,000 years ago, and it is therefore possible that diversification of both species occurred there. However, we dated speciation events older than this emergence. Speciation of Nesoryzomys likely occurred on islands that emerged at least between 1.5 to $2.3 \mathrm{Ma}$. It is difficult to know where it occurred because it is recognized that volcanic islands leave little evidence of their ancient biological past, because the lava flows consume organic matter (Steadman 1986). Thus, species may have gone through events of colonization and speciation and subsequently been driven to extinction, leaving no sign (Merlen 2014). Geist et al. (2014) suggested that because the Galápagos archipelago is dynamic over evolutionary timescales, for any model of dispersal, colonization, speciation, and radiation involving island geography more than 20,000 years ago, the current map of the Galápagos Islands is close to 
irrelevant. Despite these problems, we suggest that future studies using genome-wide molecular markers and sampling of extinct species and fossils from the islands, as well as additional continental species, will add further insights into the origin and relationships of the endemic rodents of the Galápagos Islands, which remain ambiguous.

\section{Acknowledgements}

We thank Lillian D. Parker for the valuable comments on the manuscript and Diana López-Higareda for helping with the map. Permits for field collecting were provided by Parque Nacional Galápagos to R. C. Dowler and C. W. Edwards. We thank numerous field assistants and the Charles Darwin Research Station for logistic support. Funds for field aspects of this research were provide by the Research Enhancement Program, Angelo State University and the National Geographic Society (grant \#6517-99). We also thank James L. Patton and the Museum of Vertebrate Zoology, as well as Loren K. Ammerman and the Angelo State Natural History Collections for loan of tissues.

\section{Literature cited}

Bandelt H., P. Forster, and A. RöHl. 1999. Median-joining networks for inferring intraspecific phylogenies. Molecular Biology and Evolution 16:37-48.

Benavides, E., R. Baum, D. McClellan, and J. W. Sites JR. 2007. Molecular phylogenetics of the lizard genus Microlophus (Squamata: Tropiduridae): aligning and retrieving indel signal from nuclear introns. Systematics Biology 56:776-797.

BEST, T. L. 1988. Dipodomys spectabilis. Mammalian Species 311:1-10.

Bouckaert, R., J. Heled, D. Kühnert, T. Vaughan, C-H. Wu, D. Xie, M. A. Suchard, A. Rambaut, and A. J. Drummond. 2014. BEASt 2: A Software Platform for Bayesian Evolutionary Analysis. PLoS Computational Biology 10:e1003537.

Brosset, A. 1963. Statut actuel des mammiferes des iles Galápagos. Mammalia 27:323- 338.

Cabrera, A. 1961. Catálogo de los mamíferos de América del Sur. Revista del Museo Argentino de Ciencias Naturales 'Bernardino Rivadavia'. Ciencias Zoologicas 4:309-732.

Caccone, A., J. P. Gibbs, V. Ketmaier, E. Suatoni, And J. R. Powell. 1999. Origin and evolutionary relationships of giant Galápagos tortoises. Proceedings of the National Academy of Science of the United States of America 96:223-228.

Christie, D. M., R. A. Duncan, A. R. McBirney, M. A. Richards, W. M. White, K. S. HARPP, AND G. G. Fox. 1992. Drowned islands downstream from the Galápagos hotspot imply extended speciation times. Nature 355:246-248.

Clark, D. A. 1984. Native land mammals. Pp. 225-231 in Key environments: Galápagos (Perry, R. ed.). Pergamon Press. Oxford, U.K.

CLARK, D. B. 1980. Population ecology of an endemic Neotropical island rodent: Oryzomys bauri of Santa Fe Island, Galapagos, Ecuador. Journal of Animal Ecology 49:185-198.

Darriba D., G. L. Taboada, R. Doallo, and D. Posada. 2012. jModelTest 2: more models, new heuristics and parallel computing. Nature Methods 9:772.

Deli, T., S. Fratinl, L. Ragionieri, K. Said, N. Chatti, and C. D. Schubart.
2016. Phylogeography of the marbled crab Pachygrapsus marmoratus (Decapoda, Grapsidae) along part of the African Mediterranean coast reveals genetic homogeneity across the Siculo-Tunisian Strait versus heterogeneity across the Gibraltar Strait. Marine Biology Research 12:471-487.

Dexter, N., R. C. Dowler, J. P. Flanagan, S. Hart, M. A. Revelez, and T. E. LeE. 2004. The influence of Feral Cats Felis catus on the distribution and abundance of introduced and endemic Galapagos rodents. Pacific Conservation Biology 10:210-215. do Prado, J. R., and A. R. Percequillo. 2018. Systematics studies of the genus Aegialomys Weksler et al., 2006. (Rodentia: Cricetidae: Sigmodontinae): Geography variation, species delimitation, and biogeography. Journal of Mammalian Evolution 25:71-118.

Dowlek, R. C. 2015. Genus Nesoryzomys. Pp. 390-393 in Mammals of South America. Volume 2. (Patton, J. L., U. F. J. Pardiñas, and G. D'Elía, eds.). The University of Chicago Press. Chicago, U.S.A.

Dowler, R. C., AND D. S. CARroll. 1996. The endemic rodents of Isla Fernandina: population status and conservation issues. Noticias de Galápagos 57:8-13.

DoWler, R. C., D. S. Carroll, AND C. W. EdWARDs. 2000. Rediscovery of rodents (Genus Nesoryzomys) considered extinct in the Galápagos Islands. Oryx 34:109-117.

Drummond, A. J., and A. Rambaut. 2007. BEAST: Bayesian evolutionary analysis by sampling trees. BMC Evolutionary Biology 7:214.

ExCoffIER, L. 2004. Patterns of DNA sequence diversity and genetic structure after a range expansion: lessons from the infinite-island model. Molecular Ecology 13:853-864.

Fu, Y.X. 1997. Statistical tests of neutrality of mutations against population growth, hitchhiking and background selection. Genetics 147:915-925.

GEIST, D. 1984. On the emergence and submergence of the Galápagos islands. Noticias de Galápagos 56:5-9.

Geist, D., B. A. Diefenbach, D. J. Fornari, M. D. Kurz, K. Harpp, and J. BLusztAjn. 2008. Construction of the Galápagos platform by large submarine volcanic terraces. Geochemestry Geophysics Geosystems 9: doi:10.1029/2007GC001795.

Geist, D. J., H. Snell, H. Snell, C. Goddard, and M. D. Kurz. 2014. A paleogeographic model of the Galápagos Islands and biogeographical and evolutionary implications. Pp. 145-167 in The Galápagos A natural laboratory for earth sciences. (Harpp, K. S., E. Mittelstaedt, N. d'Ozouville, and D. W. Graham, eds.). John Wiley and Sons, Inc. Hoboken, U.S.A.

González-ItTig, R. E., G. R. Theiler, and C. N. Gardenal. 2002. A contribution to the subgeneric systematics of Oligoryzomys (Rodentia, Muridae) from Argentina by means of PCR-RFLP patterns of mitochondrial DNA. Biochemical Systematics and Ecology 30:23-33.

Guindon S., AND O. Gascuel. 2003. A simple, fast and accurate method to estimate large phylogenies by maximumlikelihood. Systematic Biology 52:696-704.

HARPENDING, H. C. 1994. Signature of ancient populationgrowth in a low-resolution mitochondrial DNA mismatch distribution. Human Biology 66:591-600.

HaRPENDING, H., and A. Rogers. 2000. Genetic perspectives on human origins and differentiation. Annual Review of 
Genomics and Human Genetics 1:361-385.

Harpp, K.S., E. Mittelstaedt, N. d'Ozouville, and D. W. Graham (eds.). 2014. The Galápagos A natural laboratory for earth sciences. John Wiley and Sons, Inc. Hoboken, U.S.A.

HarRIS, D. B., S. D. Gregory, and D. W. Macdonald. 2006. Space invaders? A search for patterns underlying the coexistence of alien black rats and Galápagos rice rats. Oecologia 149:276-288.

Harris, D. B., AND D. W. Macdonald. 2007. Population ecology of the endemic rodent Nesoryzomys swarthi in the tropical desert of the Galápagos Islands. Journal of Mammalogy 88:208-219.

Heller, E. 1904. Mammals of the Galápagos archipelago, exclusive of the Cetacea. Proceedings of the California Academy of Sciences 3:233-251.

Hendriks, K. P., G. Alciatore, M. Schilthuizen, and R. S. Etienne. 2019. Phylogeography of Bornean land snails suggests long-distance dispersal as a cause of endemism. Journal of Biogeography 46:1-13.

Hirota, T., Hirohata, T., Mashima H., Satoh, T., and Y. Obara. 2004. Population structure af large Japanese field mouse, Apodemus speciosus (Rodentia: Muridae), in suburban landscape, based on mitochondrial D-loop sequences. Molecular Ecology 13:3275-3282.

HuelsenbeCK, J. P., and F. Ronquist. 2001. MRBAYES: Bayesian inference of phylogeny. Bioinformatics 17:754-755.

Hutterer, R., AND U. HiRSCH. 1980. Ein neuer Nesoryzomys von der Insel Fernandina, Galápagos. Bonner Zoologische Beitrage 30:276-283.

Hutterer, R., AND P. Oromí. 1993. La rata gigante de la Isla Santa Cruz, Galápagos: algunos datos y problemas. Resultados científicos del proyecto Galápagos: patrimonio de la humanidad. Museo de Ciencias Naturales, Tenerife (TFMC) 4:63-76.

IUCN (International Union for Conservation of Nature). 1996. IUCN Red List of Threatened Animals. IUCN, Gland, Switzerland.

IUCN (International Union for Conservation of Nature). 2019. The IUCN Red List of Threatened Species. International Union for Conservancy of Nature and Natural Resources. Version 20191. Available on http://www.iucnredlist.org. Downloaded on 05 June 2019.

Key, G., And E. Muñoz-HerediA. 1994. Distribution and current status of rodents in the Galápagos. Noticias de Galápagos 53:21-25.

Kizirian, D., A. Trager, M. A. Donnelly, and J. W. Wright. 2004. Evolution of Galápagos Island lava lizards (Iguania: Tropiduridae: Microlophus). Molecular Phylogenetics and Evolution 32:761-769.

Larkin, M. A., G. Blackshields, N. P. Brown, R. Chenna, P. A. McGettigan, H. McWilliam, F. Valentin, I. M. Wallace, A.Wilm, R. Lopez, J. D. Thompson, T. J. GiBson, And D. G. Higgins. 2007. Clustal W and Clustal X version 2.0. Bioinformatics 23:2947-2948.

Leigh, J. W., AND D. Bryant. 2015. PopART: Full-feature software for haplotype network construction. Methods in Ecology and Evolution 6:1110-1116.

Leite, R. N., S. O. Kolokotronis, F. C. Almeida, F. P. Werneck, D. S. Rogers, AND M. WeKSLER. 2014. In the wake of invasion: tracing the historical biogeography of the South American Cricetid radiation (Rodentia, Sigmodontinae). PlosOne 9:1-12.

LOSOS, J. B., AND R. E. RICKLEFS. 2009. Adaptation and diversification on islands. Nature 457:830-836.

Losos, J. B. 2010. Adaptive radiation, ecological opportunity, and evolutionary determinism. The American Naturalist 175:623-639.

Machado, L. F., Y. L. R. Leite, A. U. Christoff, and L. G. Giugliano. 2014. Phlogeny and biogeography of tetraphodont rodents of the tribe Oryzomyini (Cricetidae: Sigmodontinae). Zoologica Scripta 43:119-130.

Merlen, G. 2014. Plate tectonics, evolution, and the survival of species: A modern day hotspot. Pp. 128-153 in The Galápagos A natural laboratory for earth sciences (Harpp, K. S., E. Mittelstaedt, N. d'Ozouville, and D. W. Graham, eds.). John Wiley and Sons, Inc. Hoboken, U.S.A.

Meserve, P. L. 1978. Water dependence in some Chilean arid zone rodents. Journal of Mammalogy 59:217-219.

Musser, G. G., and M. D. Carleton. 1993. Family Muridae. Pp. 501-755 in Mammal species of the world: a taxonomic and geographic reference (Wilson, D. E., and D. M. Reeder, eds.). 2nd ed. Smithsonian Institution Press. Washington, U.S.A.

Musser, G. G., And M. D. Carleton. 2005. Superfamily Muroidea. Pp. 894-1531 in Mammal species of the world: a taxonomic and geographic reference (Wilson, D. E., and D. M. Reeder, eds.). 3rd ed. Johns Hopkins University Press. Baltimore, U.S.A.

NEl, M. 1987. Molecular Evolutionary Genetics. Columbia University Press, New York, USA.

NoWAK, R.M. 1999. Walker's Mammals of the World, 6th edn. The Johns Hopkins University Press. London, U.K.

ORR, R. T. 1938. A new rodent of the genus Nesoryzomys from the Galápagos Islands. Proceedings of the California Academy of Sciences Series 4 23:303-306.

Parada, A., U. F. J. Pardiñas, J. Salazar-Bravo, G. D'Elía, and R. E. Palma. 2013. Dating an impressive Neotropical radiation: Molecular time estimates for the Sigmodontinae (Rodentia) provide insights into its historical biogeography. Molecular Phylogenetics and Evolution 66:960-968.

Parent, C. E., A. Caccone, and K. Petren. 2008. Colonization and diversification of Galápagos terrestrial fauna: a phylogenetic and biogeographical synthesis. Philosophical Transactions of the Royal Society B 363:3347-3361.

Patton, J. L. 1975. Biosystematics of the rodent fauna of the Galápagos Archipelago. American Philosophical Society Year Book 1975:352-353.

Patton, J. L. 1984. Genetical processes in the Galápagos. Biological Journal of the Linnean Society 21:97-111.

PATTON, J. L., AND M. S. HAFner. 1983. Biosystematics of the native rodents of the Galápagos Archipelago, Ecuador. Pp. 539-568 in Patterns of evolution in Galapagos organisms (Bowman, R. I., M. Berson, and A. E. Leviton, eds.). AAAS Pacific Division. San Francisco, U.S.A.

Peterson, R. L. 1966. Recent mammal records from the Galapagos Islands. Mammalia 30:441-445.

Philippe, H., H. Brinkmann, D. V. Lavrov, D. T. J. Littlewood, M. Manuel, G. Wörheide, And D. Baurain. 2011. Resolving difficult phylogenetic questions: Why more sequences are not enough. Plos Biology 9:1-10.

Pine, R. H., R. M. Timm, ANd M. Weksler. 2012. A new recognized clade of trans-Andean Oryzomyini (Rodentia:Cricetidae), with description of a new genus. Journal of Mammalogy 
93:851-870.

Rambaut A., A. J. Drummond, D. Xie, G. Baele, and M. A. Suchard. 2018. Posterior summarization in Bayesian phylogenetics using Tracer 1.7. Systematic Biology 67:901-904.

RAmos-Onsins S. E., AND J. RozAS. 2002. Statistical properties of new neutrality tests against population growth. Molecular Biology and Evolution 19:2092-2100.

Ray, N., M. CurRat, And L. Excoffier. 2003. Intra-Deme molecular diversity in spatially expanding populations. Molecular Biology and Evolution 20:76-86.

Ribeiro, M. D. S., P. L. B. Da Rocha, L. A. F. Mendes, S. F. Perry, and E. S. De Oliveira. 2004. Physiological effects of short-term water deprivation in the South American sigmodontine rice rat Oligoryzomys nigripes and water rat Nectomys squamipes within a phylogenetic context. Canadian Journal of Zoology 82:1326-1335.

Robins, J. H., V. Tintinger, K. P. Aplin, M. Hingston, E. MatisooSmith, D. Penny, and S. D. Lavery. 2014. Rapid radiation and morphological similarity of New Guinean species. PlosOne 9:e107667.

Rodrigues, J. F. M., AND J. A. F. Diniz-Filho. 2016. Ecological opportunities, habitat, and past climatic fluctuations influenced the diversification of modern turtles. Molecular Phylogenetics and Evolution 101:352-358.

Rogers, A. R., and H. C. Harpending. 1992. Population growth makes waves in the distribution of pairwise genetic differences. Molecular Biology and Evolution 9:552-569.

RomÁn-Palacios, C., AND J. J. Wiens. 2018. The tortoise and the finch: Testing for island effects on diversification using two iconic Galápagos radiations. Journal of Biogeography 45:1701-1712.

Ronquist, F., and J. P. Huelsenbeck. 2003. MRBAYES 3: Bayesian phylogenetic inference under mixed models. Bioinformatics 19:1572-1574.

Rozas J., A. Ferrer-Mata, J. C. Sánchez-Del Barrio, S. Guirao-Rico, P. Librado, S. E. Ramos-Onsins, A. Sánchez-Gracia. 2017. DnaSP 6: DNA Sequence Polymorphism Analysis of Large Data Sets. Molecular Biology and Evolution 34:3299-3302.

SLATKIN M., AND R. R. Hudson. 1991. Pairwise comparisons of mitochondrial DNA sequences in stable and exponentially growing populations. Genetics 129:555-562.

Snell, H. M., P. A. Stone, and H. L. Snell. 1996. A summary of geographical characteristics of the Galápagos Islands. Journal Biogeography 23:619-624.

Steadman, D. W. 1985. Vertebrate paleontology of the Galápagos Islands. National Geographic Society Research Reports 20:717-724.

Steadman, D. W. 1986. Holocene Vertebrate Fossils from Isla Floreana, Galápagos. Smithsonian contributions to zoology, Number 413, Smithsonian Institution Press. Washington, U.S.A.

TAJIMA, F. 1989a. Statistical method for testing the neutral mutation hypothesis by DNA polymorphism. Genetics 123:585-595.

TAJIMA, F. 1989b. The effect of change in population size on DNA polymorphism. Genetics 123:597-601.

Urgolti, J., Muñoz, A., Espelta, J. M., and R. Bonal. 2018. Distribution and space use of seed-dispersing rodents in central Pyrenees: implications for genetic diversity, conservation and plan recruitment. Integrative Zoology 13:307-3138.

WEKSLER, M. 2003. Phylogeny of Neotropical oryzomyine rodents (Muridae: Sigmodontinae) based on the nuclear IRBP exon. Molecular Phylogenetics and Evolution 29:331-349.

WeKSLER, M. 2006. Phylogenetic relationships of oryzomyine rodents (Muroidea: Sigmodontinae): separate and combined analysis of morphological and molecular data. Bulletin of the American Museum of Natural History 296:1-149.

Weksler, M., A. R. Percequillo, and R. S. Voss. 2006. Ten new genera of oryzomyine rodents (Muridae: Sigmodontinae). American Museum Novitates 3537:1-29.

Weksler, M., and A. R. Percequillo. 2011. Key to the genera of the tribe Oryzomyini (Rodentia: Cricetidae: Sigmodontinae). Mastozoología Neotropical 18:281-292.

Werner, R., K. Hoernle, P. van den Bogaard, C. Ranero, and R. von HUENE. 1999. Drowned 14-m.y.-old Galápagos Archipelago off the coast of Costa Rica: implications for tectonic and evolutionary models. Geology 27:499-502.

Wilke, T., R. Schultheiss, and C. Albrecht. 2009. A time goes by: A simple fool's guide to molecular clock approaches in vertebrates. American Malacological Bulletin 27:25-45.

Associated editor: Lazaro Guevara

Submitted: Junio 17, 2019; Reviewed: July 1, 2019;

Accepted:September 6, 2019; Published on line:September 20, 2019. 


\section{Appendix 1}

List of individuals used in this study, indicating ID (identity) manuscript, ID collection, genus, species, name of the island, locality (if it was available), sex, kind of tissue (L - Liver, K - Kidney, H - Heart, E - Ear, S - Swab, and F - Feces), and GenBank accession number data.

\begin{tabular}{|c|c|c|c|c|c|c|c|c|}
\hline ID manuscript & $\begin{array}{c}\text { Collection } \\
\text { Number (ASNHC) }\end{array}$ & Genus & Species & Island & Locality & Sex & Tissue & $\begin{array}{c}\text { GenBank } \\
\text { accession } \\
\text { numbers }\end{array}$ \\
\hline B003SF_A.galapagoensis & ASK 4110 & Aegialomys & galapagoensis & Santa Fé & & M & - & MN398993 \\
\hline B005SF_A.galapagoensis & ASK 5643 & Aegialomys & galapagoensis & Santa Fé & & $\mathrm{F}$ & L & MN398994 \\
\hline B006SF_A. galapagoensis & ASK 5644 & Aegialomys & galapagoensis & Santa Fé & & $\mathrm{F}$ & L & MN398995 \\
\hline B036SF_A.galapagoensis & ASK 4106 & Aegialomys & galapagoensis & Santa Fé & & M & $\mathrm{KL}$ & MN398996 \\
\hline B038SF_A. galapagoensis & ASK 4111 & Aegialomys & galapagoensis & Santa Fé & & $\mathrm{F}$ & - & MN398997 \\
\hline B039SF_A.galapagoensis & ASK 5601 & Aegialomys & galapagoensis & Santa Fé & & M & $\mathrm{L}$ & MN398998 \\
\hline B041SF_A.galapagoensis & ASK 5603 & Aegialomys & galapagoensis & Santa Fé & & M & L & MN398999 \\
\hline B042SF_A. galapagoensis & ASK 5604 & Aegialomys & galapagoensis & Santa Fé & & $\mathrm{F}$ & L & MN399000 \\
\hline B043SF_A.galapagoensis & ASK 5594 & Aegialomys & galapagoensis & Santa Fé & & - & L & MN399001 \\
\hline B044SF_A. galapagoensis & ASK 5595 & Aegialomys & galapagoensis & Santa Fé & & $\mathrm{F}$ & L & MN399002 \\
\hline B046SF_A.galapagoensis & ASK 5597 & Aegialomys & galapagoensis & Santa Fé & & $\mathrm{F}$ & $\mathrm{L}$ & MN399003 \\
\hline B047SF_A.galapagoensis & ASK 5598 & Aegialomys & galapagoensis & Santa Fé & & - & L & MN399004 \\
\hline B048SF_A. galapagoensis & ASK 5599 & Aegialomys & galapagoensis & Santa Fé & & M & L & MN399005 \\
\hline B049SF_A.galapagoensis & ASK 5600 & Aegialomys & galapagoensis & Santa Fé & & $\mathrm{F}$ & L & MN399006 \\
\hline B050SF_A. galapagoensis & ASK 5593 & Aegialomys & galapagoensis & Santa Fé & & M & L & MN399007 \\
\hline B199SF_A.galapagoensis & SF-01 & Aegialomys & galapagoensis & Santa Fé & & $\mathrm{F}$ & ES & MN399008 \\
\hline B200SF_A.galapagoensis & SF-02 & Aegialomys & galapagoensis & Santa Fé & & $\mathrm{F}$ & $\mathrm{EF}$ & MN399009 \\
\hline B201SF_A. galapagoensis & SF-03 & Aegialomys & galapagoensis & Santa Fé & & $\mathrm{F}$ & $\mathrm{EF}$ & MN399010 \\
\hline B202SF_A.galapagoensis & SF-04 & Aegialomys & galapagoensis & Santa Fé & & M & $\mathrm{EF}$ & MN399011 \\
\hline B203SF_A. galapagoensis & SF-05 & Aegialomys & galapagoensis & Santa Fé & & $\mathrm{F}$ & $\mathrm{EF}$ & MN399012 \\
\hline B206SF_A. galapagoensis & SF-08 & Aegialomys & galapagoensis & Santa Fé & & $\mathrm{F}$ & $\mathrm{EF}$ & MN399013 \\
\hline B207SF_A.galapagoensis & SF-09 & Aegialomys & galapagoensis & Santa Fé & & $\mathrm{F}$ & $\mathrm{EF}$ & MN399014 \\
\hline B208SF_A.galapagoensis & SF-10 & Aegialomys & galapagoensis & Santa Fé & & M & $\mathrm{EF}$ & MN399015 \\
\hline B209SF_A.galapagoensis & SF-11 & Aegialomys & galapagoensis & Santa Fé & & M & $\mathrm{EF}$ & MN399016 \\
\hline B210SF_A. galapagoensis & SF-12 & Aegialomys & galapagoensis & Santa Fé & & $\mathrm{F}$ & $\mathrm{EF}$ & MN399017 \\
\hline B211SF_A.galapagoensis & SF-13 & Aegialomys & galapagoensis & Santa Fé & & - & $\mathrm{F}$ & MN399018 \\
\hline B215SF_A.galapagoensis & SF-17 & Aegialomys & galapagoensis & Santa Fé & & M & ES & MN399019 \\
\hline B217SF_A. galapagoensis & SF-19 & Aegialomys & galapagoensis & Santa Fé & & $\mathrm{F}$ & ES & MN399020 \\
\hline B218SF_A.galapagoensis & SF-20 & Aegialomys & galapagoensis & Santa Fé & & $\mathrm{F}$ & ES & MN399021 \\
\hline B219SF_A. galapagoensis & SF-21 & Aegialomys & galapagoensis & Santa Fé & & $\mathrm{F}$ & ES & MN399022 \\
\hline B220SF_A. galapagoensis & SF-22 & Aegialomys & galapagoensis & Santa Fé & & M & ES & MN399023 \\
\hline B221SF_A.galapagoensis & SF-23 & Aegialomys & galapagoensis & Santa Fé & & $\mathrm{F}$ & ES & MN399024 \\
\hline B222SF_A.galapagoensis & SF-24 & Aegialomys & galapagoensis & Santa Fé & & $\mathrm{F}$ & ES & MN399025 \\
\hline B223SF_A. galapagoensis & SF- 25 & Aegialomys & galapagoensis & Santa Fé & & $\mathrm{F}$ & ES & MN399026 \\
\hline B224SF_A. galapagoensis & SF-26 & Aegialomys & galapagoensis & Santa Fé & & M & ES & MN399027 \\
\hline B225SF_A.galapagoensis & SF-27 & Aegialomys & galapagoensis & Santa Fé & & M & ES & MN399028 \\
\hline B226SF_A.galapagoensis & SF-28 & Aegialomys & galapagoensis & Santa Fé & & $\mathrm{F}$ & ES & MN399029 \\
\hline B227SF_A.galapagoensis & SF-29 & Aegialomys & galapagoensis & Santa Fé & & M & ES & MN399030 \\
\hline B231SF_A.galapagoensis & SF-33 & Aegialomys & galapagoensis & Santa Fé & & M & ES & MN399031 \\
\hline B232SF_A. galapagoensis & SF-34 & Aegialomys & galapagoensis & Santa Fé & & $\mathrm{F}$ & ES & MN399032 \\
\hline B234SF_A.galapagoensis & SF-36 & Aegialomys & galapagoensis & Santa Fé & & M & ES & MN399033 \\
\hline B235SF_A. galapagoensis & SF-37 & Aegialomys & galapagoensis & Santa Fé & & M & ES & MN399034 \\
\hline B236SF_A.galapagoensis & SF-38 & Aegialomys & galapagoensis & Santa Fé & & $\mathrm{F}$ & $\mathrm{E}$ & MN399035 \\
\hline MVZ145539_A.xanthaeolus & MVZ145539 & Aegialomys & xanthaeolus & Ecuador & & - & $\mathrm{L}$ & MN399060 \\
\hline MVZ145540_A. xanthaeolus & MVZ145540 & Aegialomys & xanthaeolus & Ecuador & & - & L & MN399061 \\
\hline N018FCD_N.narboroughi & ASK 5520 & Nesoryzomys & narboroughi & Fernandina & Cabo Douglas & M & HKL & MN399062 \\
\hline
\end{tabular}




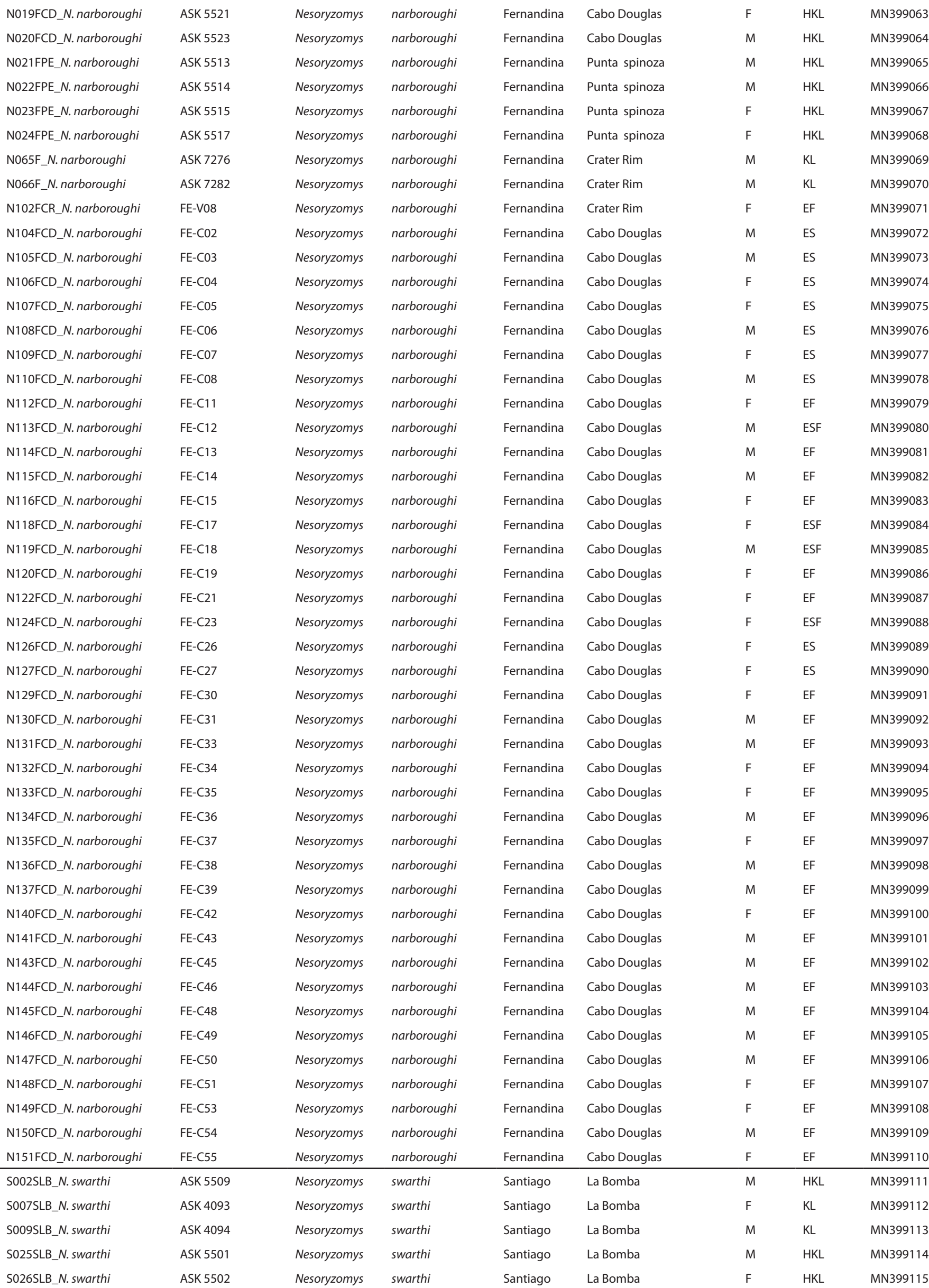




\begin{tabular}{|c|c|c|c|c|c|c|c|c|}
\hline S028SLB_N. swarthi & ASK 5505 & Nesoryzomys & swarthi & Santiago & La Bomba & $\mathrm{F}$ & HKL & MN399116 \\
\hline S029SLB_N. swarthi & ASK 5506 & Nesoryzomys & swarthi & Santiago & La Bomba & M & HKL & MN399117 \\
\hline S030SLB_N. swarthi & ASK 5511 & Nesoryzomys & swarthi & Santiago & La Bomba & $\mathrm{F}$ & HKL & MN399118 \\
\hline S051SLB_N.swarthi & ASK 5508 & Nesoryzomys & swarthi & Santiago & La Bomba & M & HKL & MN399119 \\
\hline S060SLB_N. swarthi & ASK 5500 & Nesoryzomys & swarthi & Santiago & La Bomba & $\mathrm{F}$ & HKL & MN399120 \\
\hline S152SELB_N. swarthi & SN-B01 & Nesoryzomys & swarthi & Santiago & Beach east of La Bomba & M & ES & MN399121 \\
\hline S154SELB_N. swarthi & SN-B03 & Nesoryzomys & swarthi & Santiago & Beach east of $\mathrm{La}$ Bomba & M & ES & MN399122 \\
\hline S155SELB_N. swarthi & SN-B04 & Nesoryzomys & swarthi & Santiago & Beach east of La Bomba & $\mathrm{F}$ & ES & MN399123 \\
\hline S156SELB_N.swarthi & SN-B05 & Nesoryzomys & swarthi & Santiago & Beach east of La Bomba & M & ES & MN399124 \\
\hline S157SELB_N. swarthi & SN-B06 & Nesoryzomys & swarthi & Santiago & Beach east of La Bomba & $\mathrm{F}$ & ES & MN399125 \\
\hline S158SELB_N. swarthi & SN-B07 & Nesoryzomys & swarthi & Santiago & Beach east of La Bomba & $\mathrm{F}$ & ES & MN399126 \\
\hline S159SELB_N. swarthi & SN-B08 & Nesoryzomys & swarthi & Santiago & Beach east of La Bomba & M & ES & MN399127 \\
\hline S160SELB_N. swarthi & SN-B09 & Nesoryzomys & swarthi & Santiago & Beach east of La Bomba & M & ES & MN399128 \\
\hline S161SELB_N.swarthi & SN-B10 & Nesoryzomys & swarthi & Santiago & Beach east of La Bomba & $\mathrm{F}$ & ES & MN399129 \\
\hline S162SELB_N. swarthi & SN-B11 & Nesoryzomys & swarthi & Santiago & Beach east of La Bomba & M & ES & MN399130 \\
\hline S163SELB_N. swarthi & $\mathrm{SN}-\mathrm{B} 12$ & Nesoryzomys & swarthi & Santiago & Beach east of La Bomba & $\mathrm{F}$ & ES & MN399131 \\
\hline S164SELB_N. swarthi & SN-B13 & Nesoryzomys & swarthi & Santiago & Beach east of La Bomba & $\mathrm{F}$ & ES & MN399132 \\
\hline S165SELB_N. swarthi & SN-B14 & Nesoryzomys & swarthi & Santiago & Beach east of La Bomba & $\mathrm{F}$ & ES & MN399133 \\
\hline S166SELB_N. swarthi & SN-B15 & Nesoryzomys & swarthi & Santiago & Beach east of La Bomba & M & ES & MN399134 \\
\hline S167SELB_N. swarthi & SN-B16 & Nesoryzomys & swarthi & Santiago & Beach east of La Bomba & M & ES & MN399135 \\
\hline S168SELB_N. swarthi & SN-B17 & Nesoryzomys & swarthi & Santiago & Beach east of La Bomba & M & ES & MN399136 \\
\hline S169SELB_N. swarthi & SN-B18 & Nesoryzomys & swarthi & Santiago & Beach east of La Bomba & $\mathrm{F}$ & ES & MN399137 \\
\hline S170SLB_N. swarthi & SN-LB01 & Nesoryzomys & swarthi & Santiago & La Bomba & $\mathrm{F}$ & ES & MN399138 \\
\hline S173SLB_N.swarthi & SN-LB04 & Nesoryzomys & swarthi & Santiago & La Bomba & $\mathrm{F}$ & ES & MN399139 \\
\hline S174SLB_N.swarthi & SN-LB05 & Nesoryzomys & swarthi & Santiago & La Bomba & M & ES & MN399140 \\
\hline S175SLB_N.swarthi & SN-LB06 & Nesoryzomys & swarthi & Santiago & La Bomba & $\mathrm{F}$ & ES & MN399141 \\
\hline S176SLB_N.swarthi & SN-LB07 & Nesoryzomys & swarthi & Santiago & La Bomba & M & ES & MN399142 \\
\hline S177SLB_N.swarthi & SN-LB08 & Nesoryzomys & swarthi & Santiago & La Bomba & $\mathrm{F}$ & ES & MN399143 \\
\hline S179SLB_N.swarthi & SN-LB10 & Nesoryzomys & swarthi & Santiago & La Bomba & M & $\mathrm{EF}$ & MN399144 \\
\hline S181SLB_N.swarthi & SN-LB12 & Nesoryzomys & swarthi & Santiago & La Bomba & M & $\mathrm{EF}$ & MN399145 \\
\hline S183SLB_N.swarthi & SN-LB14 & Nesoryzomys & swarthi & Santiago & La Bomba & M & $\mathrm{EF}$ & MN399146 \\
\hline S184SLB_N. swarthi & SN-LB15 & Nesoryzomys & swarthi & Santiago & La Bomba & M & $\mathrm{E}$ & MN399147 \\
\hline S185SLB_N.swarthi & SN-LB16 & Nesoryzomys & swarthi & Santiago & La Bomba & M & $\mathrm{EF}$ & MN399148 \\
\hline S186SLB_N.swarthi & SN-LB17 & Nesoryzomys & swarthi & Santiago & La Bomba & $\mathrm{F}$ & $\mathrm{EF}$ & MN399149 \\
\hline S187SLB_N. swarthi & SN-LB18 & Nesoryzomys & swarthi & Santiago & La Bomba & $\mathrm{F}$ & $\mathrm{EF}$ & MN399150 \\
\hline S188SLB_N.swarthi & SN-LB19 & Nesoryzomys & swarthi & Santiago & La Bomba & M & $\mathrm{EF}$ & MN399151 \\
\hline S189SLB_N.swarthi & SN-LB20 & Nesoryzomys & swarthi & Santiago & La Bomba & M & $\mathrm{EF}$ & MN399152 \\
\hline S191SLB_N.swarthi & SN-LB22 & Nesoryzomys & swarthi & Santiago & La Bomba & $\mathrm{M}$ & $\mathrm{EF}$ & MN399153 \\
\hline F010FCD_N.fernandinae & ASK 5567 & Nesoryzomys & fernandinae & Fernandina & Cabo Douglas & $\mathrm{F}$ & L & MN399036 \\
\hline F011FCD_N.fernandinae & ASK 5568 & Nesoryzomys & fernandinae & Fernandina & Cabo Douglas & M & L & MN399037 \\
\hline F012FCD_N.fernandinae & ASK 5569 & Nesoryzomys & fernandinae & Fernandina & Cabo Douglas & M & L & MN399038 \\
\hline F013FCD_N.fernandinae & ASK 5571 & Nesoryzomys & fernandinae & Fernandina & Cabo Douglas & $\mathrm{F}$ & L & MN399039 \\
\hline F014FCD_N.fernandinae & ASK 5572 & Nesoryzomys & fernandinae & Fernandina & Cabo Douglas & M & L & MN399040 \\
\hline F015FCD_N.fernandinae & ASK 5562 & Nesoryzomys & fernandinae & Fernandina & Cabo Douglas & $\mathrm{F}$ & $\mathrm{L}$ & MN399041 \\
\hline F016FCD_N.fernandinae & ASK 5563 & Nesoryzomys & fernandinae & Fernandina & Cabo Douglas & $\mathrm{F}$ & L & MN399042 \\
\hline F017FCD_N.fernandinae & ASK 5566 & Nesoryzomys & fernandinae & Fernandina & Cabo Douglas & $\mathrm{F}$ & L & MN399043 \\
\hline F083FCR_N. fernandinae & FE-V05 & Nesoryzomys & fernandinae & Fernandina & Crater Rim & M & ESF & MN399044 \\
\hline F084FCR_N.fernandinae & FE-V06 & Nesoryzomys & fernandinae & Fernandina & Crater Rim & M & ESF & MN399045 \\
\hline F085FCR_N. fernandinae & FE-V07 & Nesoryzomys & fernandinae & Fernandina & Crater Rim & $\mathrm{F}$ & ESF & MN399046 \\
\hline F086FCR_N.fernandinae & FE-V09 & Nesoryzomys & fernandinae & Fernandina & Crater Rim & M & ESF & MN399047 \\
\hline F087FCR_N. fernandinae & $\mathrm{FE}-\mathrm{V} 10$ & Nesoryzomys & fernandinae & Fernandina & Crater Rim & $\mathrm{F}$ & ESF & MN399048 \\
\hline F088FCR_N. fernandinae & FE-V11 & Nesoryzomys & fernandinae & Fernandina & Crater Rim & M & ESF & MN399049 \\
\hline F089FCR_N. fernandinae & FE-V12 & Nesoryzomys & fernandinae & Fernandina & Crater Rim & M & ESF & MN399050 \\
\hline
\end{tabular}




\begin{tabular}{|c|c|c|c|c|c|c|c|c|}
\hline F090FCR_N.fernandinae & FE-V13 & Nesoryzomys & fernandinae & Fernandina & Crater Rim & M & ESF & MN399051 \\
\hline F092FCR_N.fernandinae & FE-V15 & Nesoryzomys & fernandinae & Fernandina & Crater Rim & M & ESF & MN399052 \\
\hline F093FCR_N.fernandinae & FE-V16 & Nesoryzomys & fernandinae & Fernandina & Crater Rim & $\mathrm{F}$ & ESF & MN399053 \\
\hline F095FCR_N.fernandinae & FE-V18 & Nesoryzomys & fernandinae & Fernandina & Crater Rim & $\mathrm{F}$ & $\mathrm{EF}$ & MN399054 \\
\hline F096FCD_N.fernandinae & FE-C09 & Nesoryzomys & fernandinae & Fernandina & Cabo Douglas & M & $\mathrm{EF}$ & MN399055 \\
\hline F097FCD_N.fernandinae & $\mathrm{FE}-\mathrm{C} 24$ & Nesoryzomys & fernandinae & Fernandina & Cabo Douglas & M & $\mathrm{EF}$ & MN399056 \\
\hline F098FCD_N.fernandinae & FE-C29 & Nesoryzomys & fernandinae & Fernandina & Cabo Douglas & M & $\mathrm{EF}$ & MN399057 \\
\hline F099FCD_N.fernandinae & FE-C32 & Nesoryzomys & fernandinae & Fernandina & Cabo Douglas & M & $\mathrm{EF}$ & MN399058 \\
\hline F101FCD_N.fernandinae & FE-C52 & Nesoryzomys & fernandinae & Fernandina & Cabo Douglas & M & $\mathrm{EF}$ & MN399059 \\
\hline
\end{tabular}

